УДК 336.228

DOI: https://doi.org/10.37320/2415-3583/10.24

Посаднєва О.М.

кандидат економічних наук, доцент, Херсонський національний технічний університет ORCID: https://orcid.org/0000-0001-8721-5124

\title{
СОЦІОЛОГІЧНИЙ СКЛАДНИК УХИЛЕННЯ ВІД СПЛАТИ ПОДАТКІВ
}

У статті розглянуто проблематику ухилення від оподаткування з погляду впливу на девіантну поведінку платників податків морально-етичних особливостей особистості та зовнішніх економічних чинників. Наголошено, шо превалюючий вплив на рішення про порушення податкового законодавства має свідомий вибір фізичноі особи. Вплив різного роду економічних та політичних чинників на вибір податкової поведінки суб'єктів господарювання також має місие, але меншою мірою. Досліджено масштаби тіньової економіки Украӥни $і$ місие ухилення від оподаткування у формуванні теоретичного ВВП. Проаналізовано, шсо рівень тіньової економіки у динаміці зростає. Найбільший обсяг ухилень від оподаткування спостерігається у бізнесово та промислово розвинених регіонах. У розрізі видів економічної діяльності найбільше порушень податкового законодавства спостерігається у тій діяльності, яку важче проконтролювати. Основним способом ухилення від оподаткування залишається приховування реально отриманих доходів. Однак більшість платників податків боїться вагомих наслідків у разі настання покарань за порушення податкового законодавства.

Ключові слова: платники податків, ухилення, фіскальна сочіологія, податкова культура, тіньова економіка, відповідальність.

Постановка проблеми. Ухилення від оподаткування є не тільки економічним, юридичним (адміністративним та кримінальним), а й соціологічним явищем. Історичні умови розвитку тієї чи іншої держави, рівень розвиненості економіки, наявність великої або незначної кількості різних соціальних груп, усвідомлення поверненості податкових коштів за рахунок соціальних благ, рівень податкової культури та фінансової обізнаності населення значно впливають на масштаби тіньової економіки.

Безперечно, існує й кореляція між економічними циклами, а саме періодами економічних криз, періодами воєнних дій, надмірним податковим навантаженням на бізнес і т.д., i масштабами ухилення від оподаткування. Однак, як зазначають у роботі «Морально-етичні імперативи податків та оподаткування» В.Л. Андрущенко та Т.В. Тучак, «...ухилення - це людський вибір i вчинок. Адже навіть за наявності матеріальних проблем не всі поспішають уникнути податкових зобов'язань, а інші ухиляються і за відсутності проблем» [1, с. 211]. Не можна не погодитися із цією тезою. Якщо йдеться про фізичних осіб - платників податків, то в основі прийняття їх рішення про ухилення або неухилення від сплати податків усе ж таки лежить наявність сумління та розуміння приналежності до соціальної спільноти, у якій існують певні правила економічної поведінки, готовність та здатність таких фізичних осіб порушувати ці правила. Підтвердженням цього $€$ значна кількість судових процесів над відомими людьми з високим достатком, які, незважаючи на фінансову спроможність сплачувати податки, прийняли рішення про ухилення від оподаткування (футболіста Ліонеля Мессі у 2016 р. суд у Барселоні засудив за несплату податків у сумі 4,1 млн. євро; Кріштіану Роналду (футболіст) - у 2018 р. іспанський суд засудив умовно за несплату податків у розмірі 14,5 млн. євро; Шакіра Ісабель Мебарак Ріполл (співачка) у 2018 р. обвинувачена у приховувані податків на суму 14,5 млн. євро і т.д.). У перелічених вище випадках неможливо звинувачувати об'єктивні економічні обставини, у яких знаходиться людина й які спонукають до порушення податкового законодавства. Тут йдеться про відчуття егоїзму власника доходу, отриманого за результатами праці, а також про моральні орієнтири цієї людини.

3 іншого боку, юридичні особи під час прийняття рішення про ухилення від оподаткування найчастіше керуються зваженим розумінням «ризик/вигода», тобто саме на їхні рішення доволі сильно впливають економічні кризи, надмірний податковий тягар та інші об'єктивні зовнішні чинники. Про це наглядно свідчить масовість ухилень від оподаткування. Спрощено можна показати це так: у разі приховування доходів однією компанією йдеться про злочин, а за одночасного приховування доходів великою кількістю компаній - про незгоду бізнесу з податковим режимом.

Економічна і політична ситуація, що склалася нині в Україні, спонукає до обов'язкового врахування суспільної думки під час розроблення, прийняття й реалізації податкової політики та внесення змін до податкового законодавства у питаннях оподаткування юридичних і фізичних осіб. А тому питання, які традиційно постають перед фіскальною соціологією, нині для нашої держави $\epsilon$ досить актуальними.

Аналіз останніх досліджень i публікацій. Питанням урахування інтересів і мотивів суб'єктів господарювання під час формування основних 
засад оподаткування займається така течія наукової думки, як фіскальна соціологія. Її основні засади були розроблені і досліджені багатьма відомим зарубіжними теоретиками: Дж. Б'юкененом, Р. Голшейдом, Дж. О’Коннором, Дж. Кемпбеллом, Р. Масгрейвом, Г. Талоком, Й. Шумпетером, Д. Якобсом та ін.

Останнім часом і сучасна українська наукова думка спрямувала свій погляд у бік фіскально-психологічної поведінки різних суб'єктів оподаткування. Основними дослідниками засад фіскальної соціології в Україні є: В. Андрущенко, А. Крисоватий, І. Піголенко, О. Сидорович, М. Степура, О. Тимченко, Т. Тучак, В. Федосов та ін.

Мета статті полягає в окресленні основних тенденцій у поглядах платників податків на ухилення від оподаткування та тіньову економіку в часи економічних і політичних трансформацій у суспільстві.

Виклад основного матеріалу. Масштабні явища ухилення від оподаткування $є$ одним 3 індикаторів наявності i процвітання тіньової економіки в державі. Тіньова економіка включає у себе багато складників у частині порушення законодавства: корупційні дії, торгівля забороненими товарами, проведення діяльності, забороненої законом, і т.д. Однак найбільшої шкоди економіці держави завдають ухилення від оподаткування, оскільки вони є найбільшими за кількістю й обсягом утрат і призводять до недоотримання державним і місцевими бюджетами коштів, а це, своєю чергою, змушує уряд скорочувати соціальні видатки і зменшувати фінансові потоки на розвиток економіки.

Виходячи 3 того, що тіньова економіка як явище присутня в усіх країнах, питаннями i дослідження та вимірювання займаються провідні соціологічні інститути в усьому світі. В Україні такі дослідження були проведені Київським міжнародним інститутом соціології у 2019 р. в рамках проєкту SHADOW, який фінансується Європейською Комісією за програмою HORIZON2020 [6].

Дослідження базувалося на методологіï Putnins and Sauka (2015 р.), за якою розміри тіньової економіки оцінюються на основі даних вибіркового опитування підприємств із застосуванням підходу мікро-макромоделювання, котрий розділяє видимі та приховані компоненти ВВП.

Кількісне оцінювання теоретичного ВВП корисне для розуміння бюджетних утрат від тіньової економіки (ухилення від оподаткування). Завдяки такому вимірюванню стає можливим співставлення видатків, які держава може спрямувати на боротьбу з тіньовою економікою, та доходів, які вона отримує від виведення капіталу 3 тіні внаслідок цієї боротьби (рис. 1).

Оцінювання теоретичного ВВП із соціологічного та психологічного поглядів корисне для дослідження ставлення суб'єктів господарювання до економічної політики держави у цілому та податкової політики зокрема.

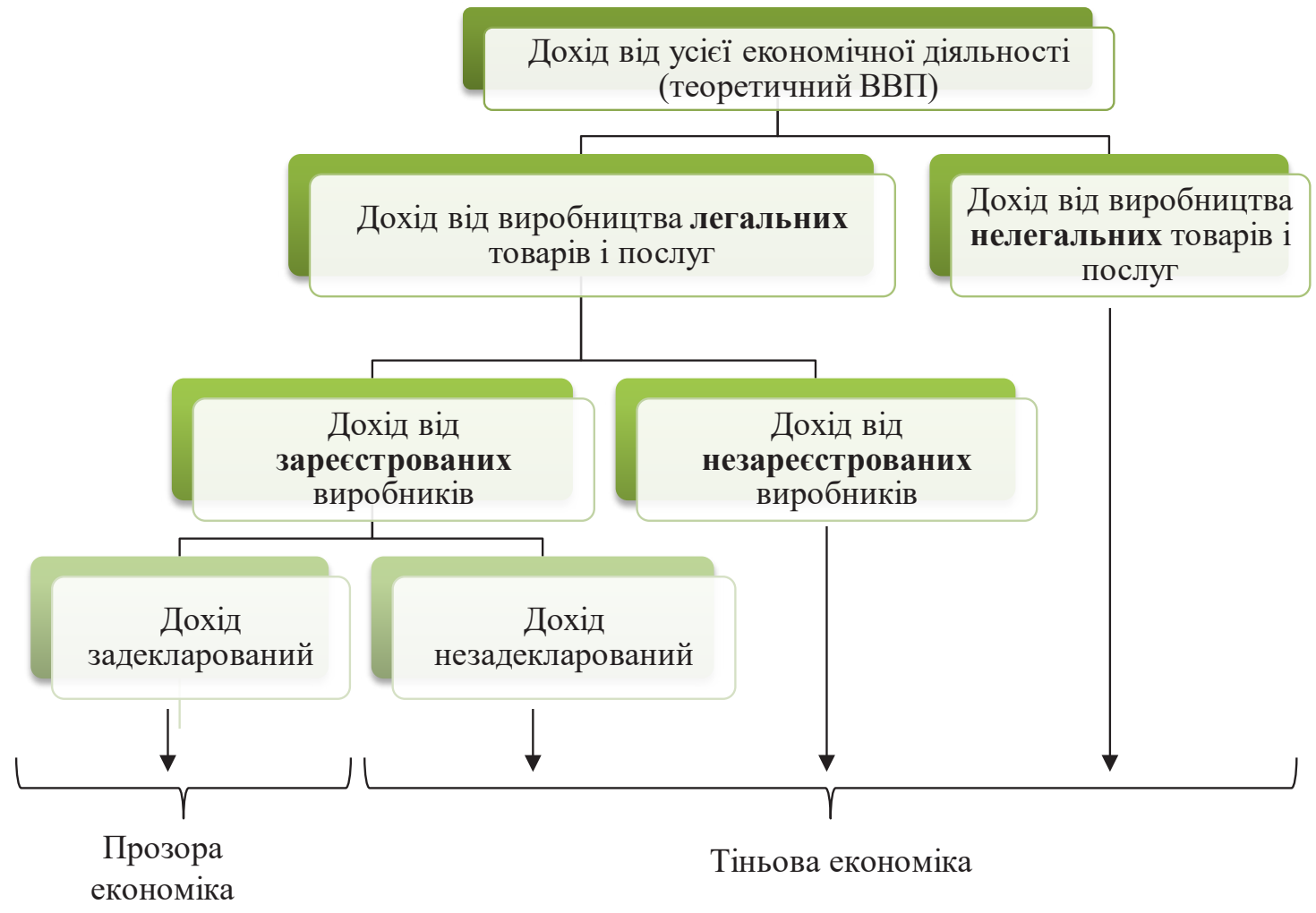

Рис. 1. Місце тіньової економіки у формуванні теоретичного ВВП 
Завдяки таким дослідженням уряд може прийняти рішення або в бік регулюючих та стимулюючих заходів (зміна ставок, надання пільг, застосування податкової амністії), або в бік каральних заходів (посилення адміністративної та кримінальної відповідальності). Такі рішення мають здебільшого залежати від визначення істинних мотивів суб'єктів господарювання, які порушують податкове законодавство.

За результатами дослідження Київського міжнародного інституту соціології, яке проводилося у березні - травні 2019 р., рівень тіньової економіки у 2018 р. збільшився порівняно з 2017 р. на 0,4 п.п. і становив 47,2\% від загального обсягу ВВП [6].

У розрізі регіонів рівень тіньової економіки розподілився так (рис. 2).

3 рис. 2 видно, що рівень тіньової економіки нерівномірний у розрізі регіонів України. Так, най- нижчий рівень спостерігається на Півдні України, а найвищий - на Півночі та у Центрі. Це здебільшого пов'язано з концентрацією бізнесу та промислових підприємств на території України. Південь відноситься до сільськогосподарського регіону, де основним видом ухилення від оподаткування $є$ відсутність реєстрації найманих працівників, а у центральних і північних регіонах більш розвиненим $\epsilon$ бізнес-середовище і тут приховуються як доходи від бізнесу, так і реальні заробітні плати.

Негативним чинником $є$ зростання тіньової економіки в динаміці, у середньому на $1,5 \%$, виняток становлять лише північні та центральні регіони країни, де відбулося зниження рівня тіньової економіки на $4,3 \%$.

Стандартно сфера роздрібної торгівлі та будівництво є секторами, які використовують особливості своєї діяльності для приховування доходів (рис. 3).

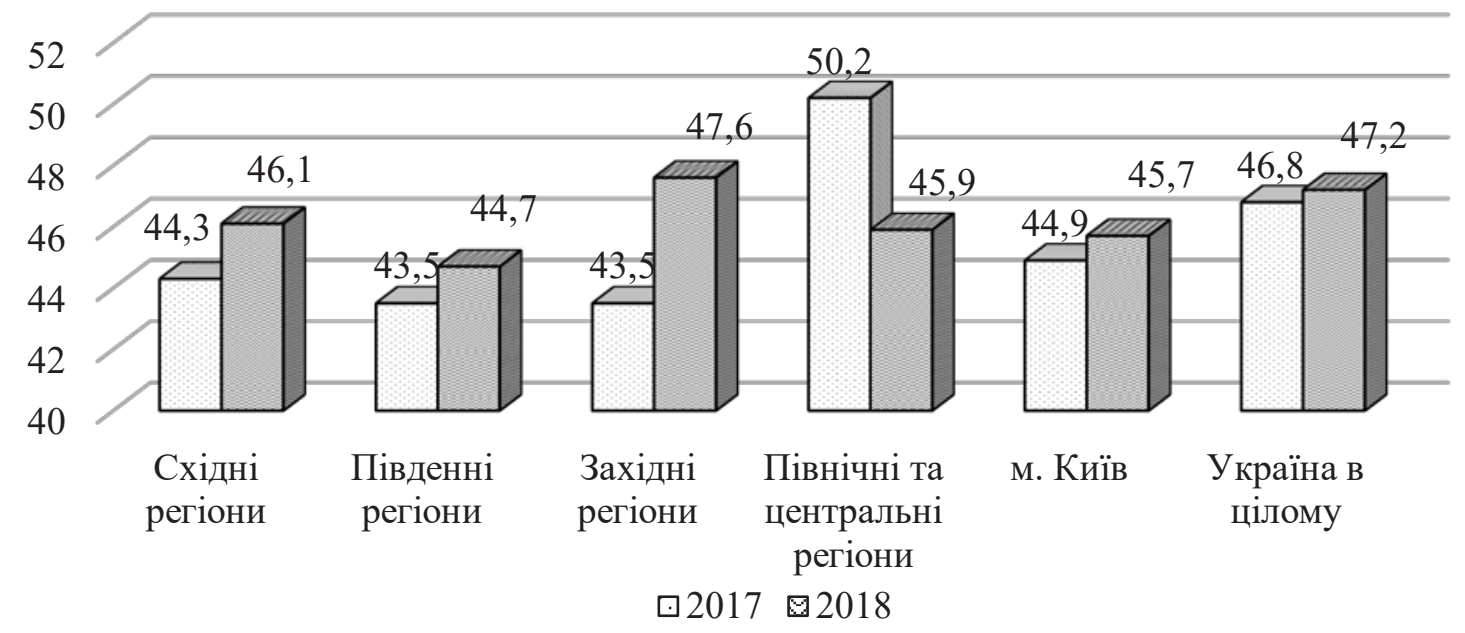

Рис. 2. Рівень тіньової економіки за регіонами України у 2017-2018 pр., \% до ВВП Джерело: складено за даними [6]

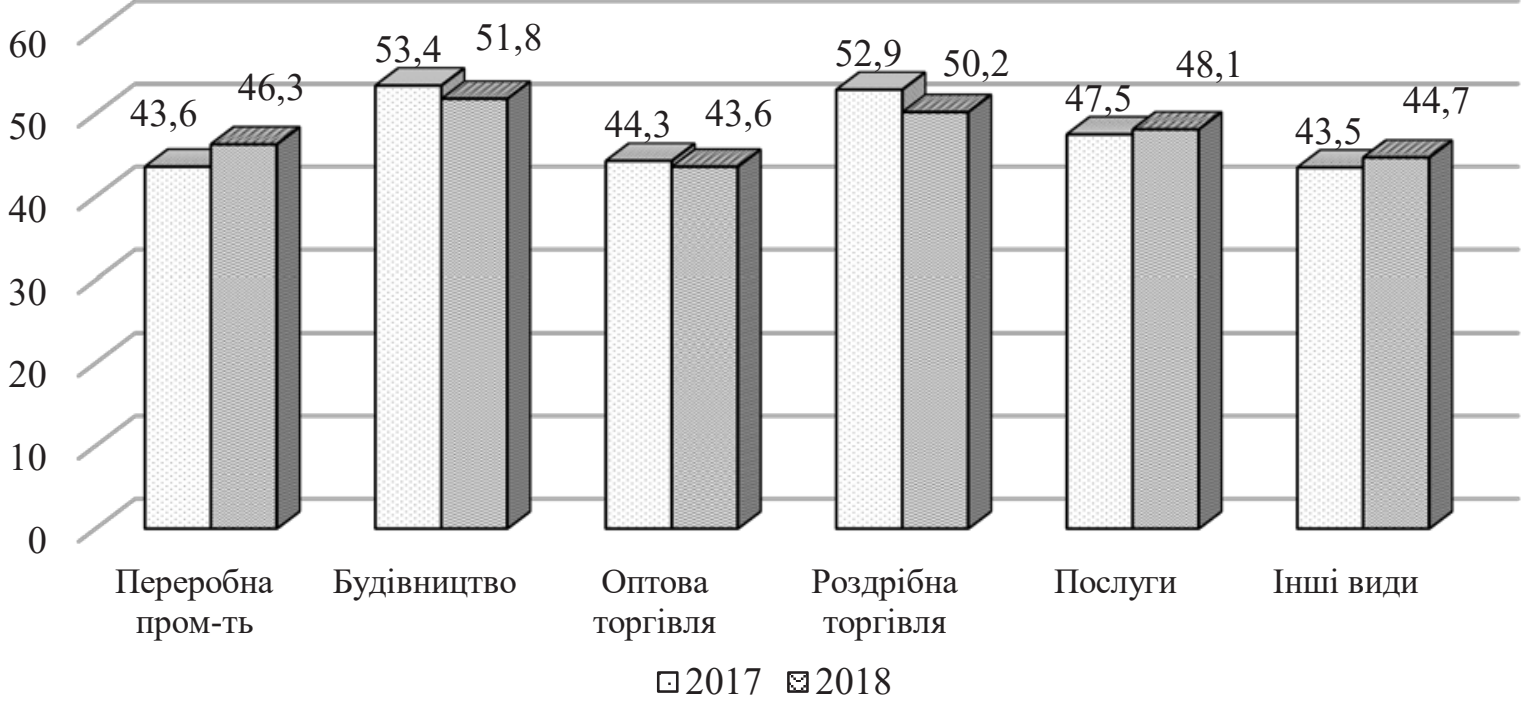

Рис. 3. Рівень тіньової економіки України у розрізі видів економічної діяльності, \% ВВП Джерело: складено за даними [6] 
Специфіка ведення обліку господарських операцій та можливості оформлення або неоформлення трудових відносин зумовлюють масштаби ухилень від оподаткування у тому чи іншому виді економічної діяльності. У даному разі не можна посилатися на важке економічне становище у державі, тут основними причинами ухилень $є$ можливості використання особливостей здійснення господарської діяльності задля порушення податкової дисципліни.

Якщо ж говорити про способи ухилень від оподаткування, то тут стандартними і найбільш поширеними $\epsilon$ :

- зменшення (приховування) доходів;

- відсутність офіційної реєстрації трудових відносин із найманими працівниками;

- приховування реальних доходів працівників (заробітна плата «у конвертах»).

Як видно з рисунку, основним правопорушенням у сфері податкового законодавства як у 2017 р., так і в 2018 р. є умисне приховування реальних доходів. Із фіскального погляду ставка податку на прибуток підприємств в Україні $\epsilon$ однією з найнижчих у Свропі (нижче лише в Угорщині та Румунії), ставка податку на доходи фізичних осіб має середній рівень [3], тобто не можна назвати причиною приховування доходів високий податковий тиск. У цьому разі скоріше йдеться про недовіру до влади, а саме про істотні сумніви в тому, що сплачені кошти у вигляді податків будуть спрямовані на поліпшення соціального й економічного становища у державі i, таким чином, повернуті громадянам у вигляді суспільних благ.

Неоформлення трудових відносин, так само як і заробітна плата «у конвертах», мінімізують лише один обов' язковий платіж для роботодавців - єдиний соціальний внесок із фонду оплати праці. Тобто 3 фінансового погляду співвідношення «ризик/доходи» для суб'єкта господарювання скоріше переважує у бік ризику, ніж доходів, однак тут у гру вступають і інтереси найманих працівників, які у силу своєї необізнаності та недовіри до держави також зацікавлені в отриманні більшої вигоди сьогодні, ніж більш високих доходів (пенсій) у майбутньому.

Фінансова необізнаність як пересічних громадян, так і суб'єктів бізнесу наочно продемонстрована на рис. 5.

3 рисунку видно, що 6,1\% респондентів уважають, що відповідальність за порушення податкового законодавства $є$ незначною, при тому що за свідоме заниження доходів вітчизняним законодавством передбачається штраф у розмірі $25 \%$ від суми заниження, а за повторний факт приховування доходів на протязі 1095 днів - 50\% суми заниження. Таке покарання складно назвати незначним. Водночас $12,1 \%$ опитаних суб'єктів господарювання вважають, що після викриття податкового шахрайства компанії доведеться припинити свою діяльність. Така міра відповідальності застосовується тільки щодо платників акцизного податку за необладнання витратомірами-лічильниками або рівномірами-лічильниками акцизних складів у разі неусунення зауважень податкових органів.

Тільки третина опитаних респондентів орієнтується у вітчизняному податковому законодавстві й у видах відповідальності за ухилення від оподаткування та бачить реальну картину фінансових наслідків своїх дій. Незважаючи на це, масштаби приховування доходів та неповного їх декларування досить великі.

Висновки. Підсумовуючи вищезазначене, слід відзначити, що негативним чинником розвитку вітчизняної економіки є зростання ії тіньового сектору. До цього призводить низка причин: у деяких видах економічної діяльності це наявність «лазівок» ухилення від оподаткування; відсутність довіри до державних інститутів, а саме до законодавчої та виконавчої влади; відсутність фінансових знань та низький рівень податкової культури,
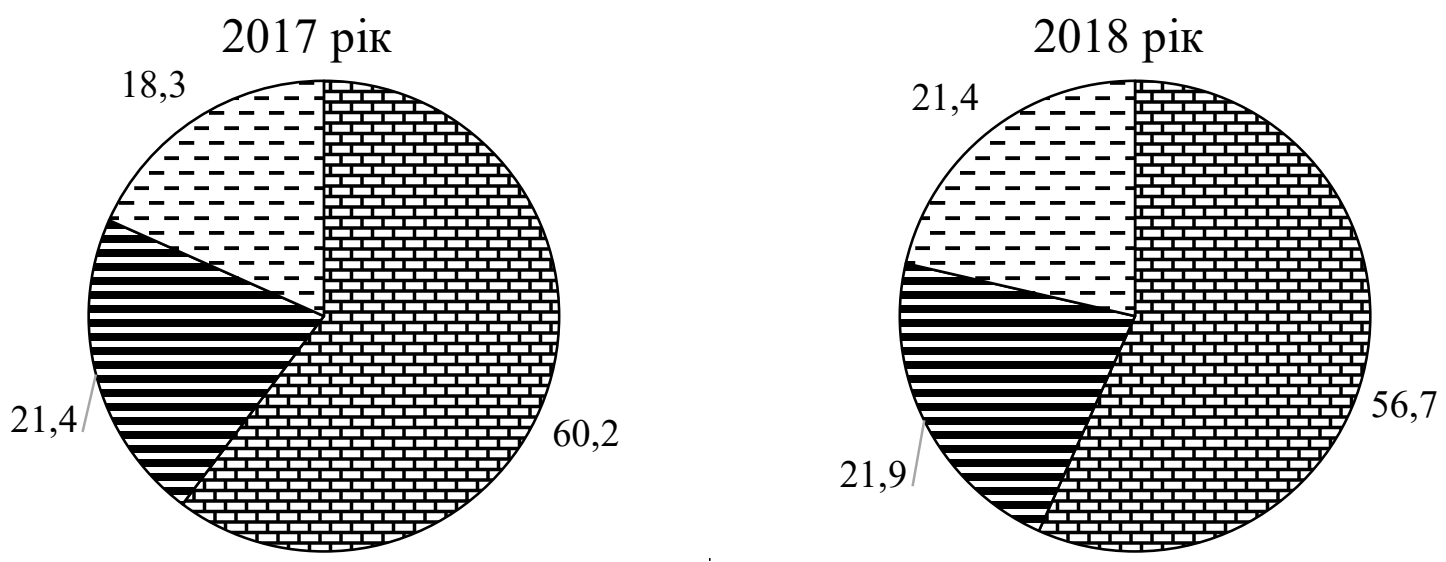

巴Приховування доходу $\boldsymbol{\nabla}$ Неоформлення трудових відносин 口Заробітна плата "у конвертах"

Рис. 4. Питома вага способів (видів) ухилень від оподаткування у 2017-2018 рр., \%

Джерело: складено за даними [6] 


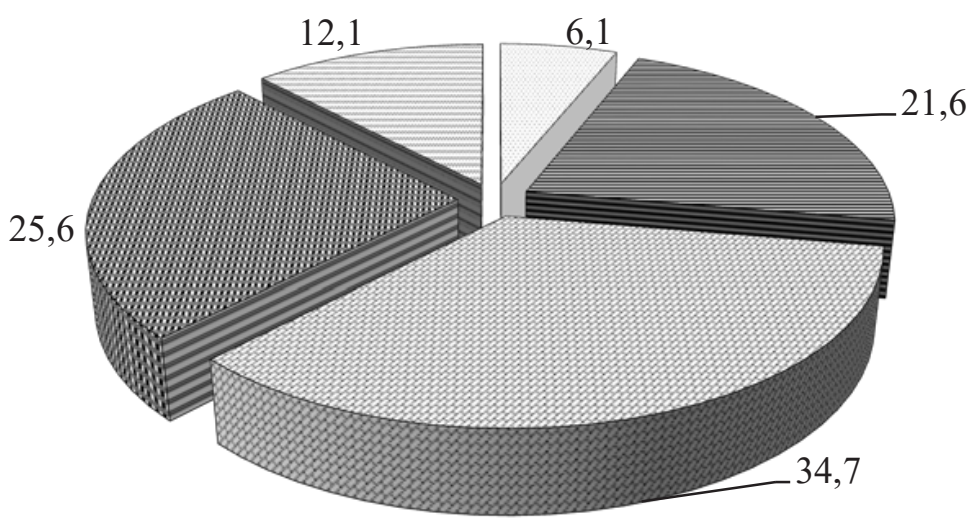

\author{
$\bullet$ Нічого серйозного \\ = Незначний штраф \\ $\square$ Відчутний штраф, який може вплинути на кокурентність компанії \\ Відчутний штраф, який може призвести до фінансових проблем або банкрутства \\ चКомпанії доведеться припинити свою діяльність
}

\title{
Рис. 5. Питома вага очікуваних покарань за свідоме заниження або приховування доходів,\% \\ Джерело: складено за даними [6]
}

який історично сформувався на пострадянському просторі. Однак позитивним чинником $\epsilon$ те, що дві третини опитаних респондентів побоюються наслідків викриття податкових шахрайств, а тому вони відкриті для діалогу з податковими органами, й альтернативним шляхом зниження масштабів тіньової економіки є встановлення фіскальними органами зв'язку з громадськістю.

\section{Список використаних джерел:}

1. Андрущенко В.Л., Тучак Т.В. Морально-етичні імперативи податків та оподаткування (західна традиція) : монографія. Київ : Алерта, 2013. 384 с.

2. Пиголенко I.В. Соціологічна складова дослідження проблеми ухилення від сплати податків. Ukrainian society. 2010. № 1. C. 64-72. URL : https://ukr-socium.org.ua/wp-content/uploads/2010/01/65-72_no-1_vol-32_2010_UKR.pdf (дата звернення: 07.02.2020).

3. Податки в Україні vs країни ЄC: де платять більше? Ціна держави. Дата оновлення: 26.03.2019. URL : http://cost.ua/news/714-podatky-v-ukrayini-vs-krayiny-eu-de-platyat-bilshe/ (дата звернення: 08.02.2020).

4. Сидорович О.Ю. Парадигми фіскальної соціології в контексті західної фінансової думки. Наукові записки. Серія «Економіка». 2011. Вип. 16. С. 543-550. URL : https://eprints.oa.edu.ua/7076/1/73.pdf (дата звернення: 06.02.2020).

5. Степура М. Фіскальна психологія платника у взаємодії з податковими органами. Ринок иінних паперів України. 2009. № 11-12. C. 9-16.

6. Тіньова економіка в Україні. Результати дослідження 2019 року. Соиіологічні та маркетингові дослідження. Київ : Київський міжнародний інститут соціології, 2019. URL : https://www.kiis.com.ua/?lang=ukr\&cat= reports\&id=897\&page=2\&t=6 (дата звернення: 08.02.2020).

\section{References:}

1. Andrushchenko V.L., Tuchak T.V. (2013) Moralno-etychni imperatyvy podatkiv ta opodatkuvannia (zakhidna tradytsiia) [Moral and ethical imperatives of taxes and taxation (western tradition)]. Kyiv : Alerta. (in Ukrainian)

2. Pyholenko I.V. (2010) Sotsiolohichna skladova doslidzhennia problemy ukhylennia vid splaty podatkiv [A sociological component of the problem of tax evasion]. UKRAINIAN SOCIETY. no. 1, pp. 64-72. Available at: https://ukr-socium.org.ua/ wp-content/uploads/2010/01/65-72_no-1_vol-32_2010_UKR.pdf (accessed 07 February 2020).

3. Price of the state (2019). Podatky v Ukraini vs krainy YeS: de platiat bilshe? [Taxes in Ukraine vs EU countries: where do they pay more?]. Available at: http://cost.ua/news/714-podatky-v-ukrayini-vs-krayiny-eu-de-platyat-bilshe/ (accessed 08 February 2020).

4. Sydorovych O.Yu. (2011) Paradyhmy fiskalnoi sotsiolohii v konteksti zakhidnoi finansovoi dumky [Fiscal sociology paradigms in the context of western financial thought]. Scientific notes. Economy series. no. 16, pp. 543-550. Available at: https://eprints.oa.edu.ua/7076/1/73.pdf (accessed 06 February 2020).

5. Stepura M. (2009) Fiskalna psykholohiia platnyka u vzaiemodii z podatkovymy orhanamy [Fiscal psychology of the payer in cooperation with tax authorities]. Securities market of Ukraine. no. 11-12, pp. 9-16.

6. Kyiv International Institute of Sociology (2019). Tinova ekonomika v Ukraini. Rezultaty doslidzhennia 2019 roku. [The shadow economy in Ukraine. The results of the 2019 survey], Kyiv : Kyiv International Institute of Sociology. Available at: https://www.kiis.com.ua/?lang=ukr\&cat=reports\&id=897\&page=2\&t=6 (accessed 08 February 2020). 
Posadnieva Oksana

Kherson National Technical University

\section{SOCIOLOGICAL COMPONENT OF TAX EVASION}

The article deals with the problem of tax evasion from the point of view of influence on the deviant behavior of taxpayers of moral and ethical characteristics of the individual. The influence of external economic and political factors is also investigated. In the research it is emphasized that the conscious choice of an individual has the main influence on the decision on violation of tax legislation. The influence of various economic and political factors on the choice of tax behavior of economic entities also takes place, but to a lesser extent. The scope of the Ukrainian shadow economy is also explored. The article shows the role and size of tax evasion in shaping theoretical GDP. It is analyzed that the level of the shadow economy is growing in dynamics. The largest amount of tax evasion is observed in economically developed regions. This tendency is explained by the higher economic benefit from tax evasion. In terms of economic activities, the most violations of tax legislation are observed in those activities that are more difficult to control. These activities include construction and retail. The main way to tax evasion is to conceal real income. This is due to the selfishness of the owner of the income generated by the work. This is also due to the lack of confidence in the legislative and executive bodies. Lack of trust in the authorities leads to a lack of confidence in the targeting of taxes and their useful spending. Lack of legislative regulation of labor relations with employees is also one of the ways of evasion that reduces budget revenues. Paying salaries «in envelopes» remains a significant problem in Ukraine. Most taxpayers fear grave consequences in the event of penalties for breach of tax law. Thus, measuring and understanding the causes of taxpayers' deviant behavior can help the government think about ways not only to punish, but also to identify possible ways to get a business out of the shadows. An alternative way of reducing the shadow economy is to set up public relations with fiscal authorities. Understanding the motives behind the interaction of taxpayers with the shadow economy can help with tax policy development.

Key words: taxpayers, evasion, fiscal sociology, tax culture, shadow economy, responsibility.

JEL classification: A14, H26. 